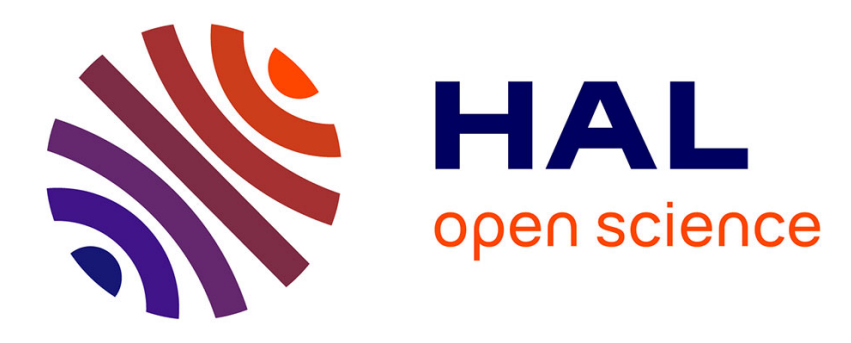

\title{
Local inflammation, endothelial dysfunction and fibrinolysis in coronary heart disease
}

\author{
Gordon Do Lowe
}

\section{To cite this version:}

Gordon Do Lowe. Local inflammation, endothelial dysfunction and fibrinolysis in coronary heart disease. Clinical Science, 2006, 110 (3), pp.327-328. 10.1042/CS20060002 . hal-00479319

\section{HAL Id: hal-00479319 https://hal.science/hal-00479319}

Submitted on 30 Apr 2010

HAL is a multi-disciplinary open access archive for the deposit and dissemination of scientific research documents, whether they are published or not. The documents may come from teaching and research institutions in France or abroad, or from public or private research centers.
L'archive ouverte pluridisciplinaire HAL, est destinée au dépôt et à la diffusion de documents scientifiques de niveau recherche, publiés ou non, émanant des établissements d'enseignement et de recherche français ou étrangers, des laboratoires publics ou privés. 


\section{EDITORIAL COMMENT}

LOCAL INFLAMMATION, ENDOTHELIAL DYSFUNCTION AND

FIBRINOLYSIS IN CORONARY HEART DISEASE

GDO Lowe

Professor of Vascular Medicine

University Department of Medicine

Royal Infirmary

10 Alexandra Parade

GLASGOW G31 2ER

United Kingdom

gdl1j@clinmed.gla.ac.uk

\section{$\underline{\text { ABSTRACT }}$}

Prospective epidemiological studies have shown associations of circulating inflammatory markers with risk of coronary heart disease (CHD); however these associations are modest after adjustment for confounding by established risk factors, and do not add significantly to the predictive value of current clinical risk scores. In contrast, experimental human studies of local arterial inflammation (such as the brachial artery infusion of TNF $\alpha$ model reported by Robinson et al) are of value in elucidating the pathophysiology of atherothrombosis.

\section{$\underline{\text { KEY WORDS }}$}

Coronary heart disease, atherothrombosis, inflammation, tumour necrosis factor $\alpha$, tissue plasminogen activator, endothelial function. 
There is increasing interest in the epidemiological associations between circulating markers of inflammation and risk of coronary heart disease (CHD), stroke and peripheral arterial disease [1]. While recent attention has focussed on C-reactive protein (CRP), meta-analyses of prospective studies have shown that several other circulating inflammatory markers show similar associations with risk of CHD. These include other reactant proteins synthesised in the liver (e.g. serum amyloid A; albumin which is a negative reactant protein; coagulation factors including fibrinogen and factor VIII; and the fibrinolytic inhibitor, plasminogen activator inhibitor type 1 PAI1) or endothelial cells (e.g. tissue plasminogen activator, tPA; PAI-1; von Willebrand factor, vWF); traditional clinical tests of disease activity which reflect plasma protein changes (plasma viscosity; erythrocyte sedimentation rate, ESR); and white cell count. The strengths of these associations are modest: typically, an increase in relative risk of CHD of about 50\% in persons in the highest third of the population distribution compared to persons in the lowest third, after adjustment for major cardiovascular risk factors [1]. Hence, their measurement is of no clinical value, because they do not add significantly to current clinical risk scores (e.g. those based on the Framingham study) in predicting CHD risk in healthy persons [1-3]. Their utility in prediction of outcome in acute coronary syndromes or stroke, and in prediction of recurrent cardiovascular events, remains to be established in further meta-analyses of relevant prospective studies [1].

While therefore of no current proven clinical relevance, inflammatory markers are of considerable pathophysiological interest, because they can help to elucidate biological mechanisms through which environmental risk factors (such as tobacco smoking and

\section{Copyright 2006 The Biochemical Society}


obesity) promote the continuing global epidemic of cardiovascular disease. Such studies can be performed at the epidemiological level [1], or at the experimental level in humans, other mammals, or mammalian cell cultures [4]. In this issue of Clinical Science, Robinson and colleagues [5] report an elegant model of acute local arterial inflammation (brachial artery infusion of the primary pro-inflammatory cytokine, tumour necrosis factor - $\alpha$, TNF $\alpha$ ), in which they studied its effects on endothelial cell release of t-PA and its inhibitor, PAI-1; as well as endothelial function (acetylcholine - and nitroprusside-induced vasodilatation , and bradykinin - induced release of t-PA). In a saline-controlled, randomised, double-blind crossover study in 12 males with stable CHD, they observed that intra-arterial TNF $\alpha$ caused a rise in tPA activity and antigen levels in the infused arm, but not the non-infused arm. TNF $\alpha$ pre-treatment impaired acetylcholine - and nitroprusside - induced vasodilatation, and augmented bradykinin - induced release of t-PA.

The value of this local model of acute inflammation, as pointed out by the authors [5], is that it avoids the induction of systemic inflammation,_which has many biological actions and could be confounded by indirect or extra-vascular effects. In epidemiological studies, circulating levels of inflammatory markers may be strongly influenced by such effects (e.g. the effects of cigarette-smoking on the respiratory tract, as well as the circulation), which may explain why they are associated with not only cardiovascular, but also non-cardiovascular mortality [1]. While previous studies in healthy volunteers have shown that acute systemic inflammation is associated with a transient impairment in vasomotor function [6], the authors have shown that such an impairment in vasomotor function can also be mediated by local inflammation [5].

\section{Copyright 2006 The Biochemical Society}


Robinson et al [5] have also shown that local infusion of TNF $\alpha$ increases both basal and bradykinin-induced local release of t-PA. While blood flow affects endothelial cell t-PA release by altering shear stress [7], TNF $\alpha$ infusion did not affect blood flow; nor did it affect PAI-1 concentrations. The authors discuss other possible mechanisms for this effect, and speculate that endothelial dysfunction, induced by inflammation, may be one of several mechanisms underlying the association of increased circulating t-PA antigen levels with risk of CHD [8]. It is, possible that increased local t-PA activity in arterial plaques may potentiate degradation of extracellular matrix and aggravate plaque instability $[9,10]$. The authors suggest that this adverse effect may at times outweigh the beneficial effect of local t-PA release in lysing intra-vascular fibrin [5].

The model reported by Robinson et al [5] merits further evaluation in illuminating the role of local arterial inflammation in pathogenesis of CHD. Possible future studies include: the effects of the other primary pro-inflammatory cytokine (interleukin-1), as well as the "messenger” pro-inflammatory cytokine interleukin-6, whose local levels were increased by TNF $\alpha$ infusion [5]; the measurement of endothelial cell products, other than t-PA and PAI-1, which are involved in thrombosis (e.g. von Willebrand factor and tissue factor); and the infusion of pro-inflammatory cytokines into arteries which (unlike the brachial artery) are affected by atherosclerosis, such as the coronary arteries. Studies of inflammation and arterial disease should focus on local effects in arteries, rather than the associations of circulating levels of inflammatory markers with risk of arterial events in epidemiological studies - which are highly confounded by the effects of multiple adverse environmental factors (such as smoking, obesity

\section{Copyright 2006 The Biochemical Society}


and low socio-economic position) which also increase risks of non-cardiovascular morbidity and mortality [1].

\section{REFERENCES}

1. Lowe GDO. Circulating inflammatory markers and risks of cardiovascular and non-cardiovascular disease. J Thromb Haemostas 2005; 3:1618-1628

2. Wilson PWF, Nam BH, Pencina M, D’Agostino RB, Benjamin EJ, O’Donnell $\mathrm{CH}$. C-reactive protein and risk of cardiovascular disease in men and women from the Framingham Heart Study. Arch Intern Med 2005; 165: 2473-2478

3. Greenland P, O’Malley PG. When is a new prediction marker useful? A consideration of lipoprotein-associated phospholipase $A_{2}$ and C-reactive protein for stroke risk. Arch Intern Med 2005; 165: 2454-2456

4. Libby P, Ridker PM, Maseri A. Inflammation and atherosclerosis. Circulation 2002; 105: 1135-1143

5. Robinson SD, Dawson P, Ludlam CA, Boon NA, Newby DE. Vascular and fibrinolytic effects of intra-arterial tumour necrosis factor- $\alpha$ in patients with coronary heart disease. Clinical Science, this issue

6. Hingorani AD, Cross J, Kharbanda RK, et al. Acute systemic inflammation impairs endothelium-dependent dilatation in humans. Circulation 2002; 102: 994-999

7. Diamond SL, Eskin SG, McIntire LV. Fluid flow stimulates tissue plasminogen activator secretion by cultured human endothelial cells. Science 1989; 248: 1483-1485

\section{Copyright 2006 The Biochemical Society}


8. Lowe GDO, Danesh J, Lewington S, Walker M, Lennon L, Thomson A, Rumley A, Whincup PH. Tissue plasminogen activator antigen and coronary heart disease: Prospective study and meta-analysis. Europ Heart J 2004; 25: $252-259$

9. DeBono D. Significance of raised plasma concentration of tissue-type plasminogen activator and plasminogen activator inhibitor in patients at risk from ischaemic heart disease. Br Heart J 1994; 71: 504-507

10. Steins MB, Padro T, Li C-X, et al. Overexpression of tissue-type plasminogen activator in atherosclerotic human coronary arteries. Atherosclerosis 1999; 145: $173-180$ 